\title{
ANTIOXIDANT MEDIATED DEFENSE ROLE OF ECLIPTAALBA HERBAL EXTRACT AGAINST CCL4 INDUCEDTOXIC HEPATITIS
}

\author{
G. PRIYA \\ PG and Research Department of Biochemistry, Mohammed Sathak College of Arts and Science \\ Email: rameshgpriya@gmail.com
}

Received: 23 Oct 2017, Revised and Accepted: 12 Dec 2017

\begin{abstract}
Objective: The present study focuses on the antioxidant mediated the protective effect of a popular medicinal herb Ecliptaalba against $\mathrm{CCl}_{4}$ induced oxidative stress in the liver of rats.

Methods: Rats divided into four groups were administered with $\mathrm{CCl}_{4}$ andCCl 4 along with methanol extract of leaves of Eclipta herb (200 and 400 $\mathrm{mg} / \mathrm{kg} \mathrm{b}$. wt) for three weeks. At the end of treatment, rats were anaesthetized and blood samples were collected for serum separation. Biochemical analysis such as alanine aminotransferase (ALT), aspartate aminotransferase (AST), alkaline phosphatase (ALP), lactate dehydrogenase (LDH) and total bilirubin (TB) was done in serum. Liver tissue was used for glutathione (GSH), lipid peroxidation (LPO), glutathione peroxidase (GPx), glutathione S-transferase (GST), superoxide dismutase (SOD) and catalase (CAT) analysis. $\mathrm{CCl}_{4}$ administration caused significant elevation of the serum enzymes and total bilirubin content.
\end{abstract}

Results: Antioxidant enzymes were drastically inhibited with a significant reduction of glutathione and increased lipid peroxidation in $\mathrm{CCl}_{4}$ treated rats. Ecliptaalba extracts administrated rats, however, did not show much changes in marker enzyme level. Antioxidant enzyme status was also not affected and found nearer to the control levels. Increased gluatathione level and reduced lipid peroxidation were also evident in Eclipta alba treated rats.

Conclusion: The findings show that Eclipta alba extract offers better protection against the free radical toxicity of $\mathrm{CCl}_{4}$.

Keywords: $\mathrm{CCl}_{4}$, Free radical, Antioxidant, Liver, Ecliptaalba

(C) 2018 The Authors. Published by Innovare Academic Sciences Pvt Ltd. This is an open access article under the CC BY license (http://creativecommons.org/licenses/by/4.0/) DOI: http://dx.doi.org/10.22159/ijcpr.2018v10i1.24406

\section{INTRODUCTION}

Liver plays an important role in metabolism, detoxification and excretion of many xenobiotic compounds. Because of its anatomical location and its great capacity for xenobiotic metabolism, it is frequently a target for toxic chemicals. Although viral infection is one of the main causes of liver injury, xenobiotics, excessive drug therapy, environmental pollutants and chronic alcohol ingestion can also cause hepatic injury. Cancer chemotherapeutic drugs caused liver toxicity has been widely reported [1]. Ecliptaalba (L.) is an annual herbaceous plant, commonly known as false daisy. It is an erect or prostrate, much branched, roughly hairy, annual, rooting at the nodes; the leaves are opposite, sessile and lanceolate. Belonging to family Asteraceae it is also known as Bhringaraj and Karisilakanni, which is found a common weed throughout India ascending up to $6000 \mathrm{ft}$. The genus name comes from the Greek word meaning "Deficient" with reference to the absence of the bristles and awns on the fruits. Main active principles consist of coumestans like wedelolactone, desmethyl wedelolactone, furanocoumarins, oleanane and taraxastane glycosides Ecliptaalba (L.) has been used in various parts of tropical and sub-tropical regions like South America, Asia, Africa. There are three kinds or Ecliptaalba-the white-flowering, the yellow-flowering, and the blackfruiting, but all three grow throughout India by marshes, rivers, and lakes or on the foothills of the Himalayas. It is an active ingredient of many herbal formulations prescribed for liver ailments and shows the effect on liver cell generation. It is used as a tonic and diuretic in hepatic and spleen enlargement. It is also used in catarrhal jaundice and for skin diseases. Most of these toxic chemicals have been reported to generate free radicals and reactive oxygen species which are the major culprits in liver pathogenesis. The improper balance between reactive metabolites production and antioxidant defence results in oxidative stress, which regulates the cellular functions leading to various pathological conditions. Free radical-mediated lipid peroxidation induced by these chemicals play a crucial role in various steps that initiate and regulate the progression of liver diseases independently of the agent in its origin [2]. The treatment for liver diseases has become a challenging problem of the modern medicine. A number of herbal preparations have been advocated for treating liver diseases. Research investigations conducted on several plant products as liver protective are well documented [3]. Because free radicals and reactive oxygen species play a central role in liver diseases pathology and progression, dietary antioxidants have been proposed as therapeutic agents to counteract liver damage [4]. Additionally, recent studies have suggested that natural antioxidants in complex mixtures ingested with the diet are more efficacious than pure compounds in preventing oxidative stress-related pathologies due to particular interactions and synergism $[5,6]$. It is evident that there is an increasing demand to evaluate the antioxidant properties of direct plant extract [7]. And there is a need for screening more bioactive plant products with antioxidant properties. In the present study, a popular medicinal plant in the Indian system of medicine Ecliptaalba was evaluated against carbon tetrachloride-induced toxic hepatitis. The plant is widely used as cholagogues and deobstruent in hepatic enlargement, for jaundice and other ailments of the gallbladder [8]. Few studies on Ecliptaalba proved to be effective in protecting the liver from $\mathrm{CCl} 4$ toxicity. However, the antioxidant mediated protective effect of this herb on $\mathrm{CCl} 4$ induced hepatopathogenesis have not been reported earlier. The present study primarily focuses on the antioxidant defence mechanisms of the plant extracts.

\section{MATERIALS AND METHODS}

\section{Plant extracts}

Fresh Ecliptaalba herbs were collected from the wild and washed thoroughly. Fresh and infection free leaves were isolated and shade dried. The dried leaves were powdered mechanically and defattened using petroleum ether solvent. The defattened plant materials were extracted with methanol using soxhlet apparatus by hot percolation method. The extract Ecliptaalba obtained was concentrated in a rotary vacuum evaporator and dissolved in DMSO for administration. 


\section{Reagents}

All reagents used for the biochemical estimations in the study were procured from Qualigens Fine Chemicals and Hi-media Laboratories Pvt Ltd, Mumbai and are analytical grade.

\section{Animals}

Male wistar rats weighing about $200 \pm 20 \mathrm{~g}$ were used for the study. They were housed in a well-conditioned room with $12 \mathrm{~h}$ light/12 h dark photoperiod. They were fed with standard animal feed (Lipton India, Bangalore, India) and water ad libitum. Experiments were conducted in accordance with the Institutional Ethical Committee Guidelines (Biotech SBU.001/09).

\section{Experimental design}

Animals were divided into 4 groups with six animals each. Group I received $0.2 \mathrm{ml}$ of DMSO intraperitoneally and treated as experimental control; Group II was administrated with $0.3 \mathrm{ml}$ of $\mathrm{CCl}_{4}$ intraperitoneally for five days for induction of toxic hepatitis; Group III received $\mathrm{CCl}_{4}$ similar to group II and $200 \mathrm{mg} / \mathrm{kg}$ bodyweight of Eclipta alba orally and Group IV rats received $\mathrm{CCl}_{4}$ and $400 \mathrm{mg} / \mathrm{kg}$ body weight of Eclipta alba extracts.

After three weeks of extract, administration rats were anaesthetized and blood samples were collected by a sino-orbital puncture. Serum separated was used for all biochemical estimations. Animals were autopsied and liver was excised carefully and washed in saline. Tissue homogenate was prepared in $0.1 \mathrm{M}$ Tris- $\mathrm{HCl}$ buffer $(\mathrm{pH} 7.4)$ and used for the determination of lipid peroxides (LPO), reduced glutathione (GSH), glutathione peroxidase (GPx), glutathione Stransferase (GST), catalase (CAT) and superoxide dismutase (SOD).

\section{Biochemical estimations}

\section{Serum aspartate and alanine transferase (AST and ALT)}

The activities of these enzymes were estimated by the method of [26]. $0.2 \mathrm{ml}$ of serum was added to $1 \mathrm{ml}$ of phosphate buffer containing substrate, mixed and incubated for $60 \mathrm{~min}$ for AST and $30 \mathrm{~min}$ for ALT at $37^{\circ} \mathrm{C}$. Then $1 \mathrm{ml}$ of dinitrophenylhydrazine was added and incubated for $20 \mathrm{~min}$ at room temperature and $10 \mathrm{ml}$ of $0.4 \%$ sodium hydroxide was added, mixed well and after five minutes read at $550 \mathrm{~nm}$. Blank and a series of standards were processed similarly.

\section{Lactate dehydrogenase (LDH)}

LDH was assayed according to the method of [16]. To $1.0 \mathrm{ml}$ of the buffered substrate (lithium lactate in $0.1 \mathrm{M}$ glycine buffer, $\mathrm{pH} 10$ ), 0.1 $\mathrm{ml}$ of enzyme preparation was added and the tubes were incubated at $37.8 \mathrm{oC}$ for $15 \mathrm{~min}$. After adding $0.2 \mathrm{ml}$ of NAD+solution, the incubation was continued for another $15 \mathrm{~min}$. The reaction was arrested by adding $0.1 \mathrm{ml}$ of DNPH (2, 4-dinitrophenyl hydrazine), and the tubes were incubated for a further period of $15 \mathrm{~min}$ at $37.80 \mathrm{C}$ after which $7.0 \mathrm{ml}$ of $4 \mathrm{~N} \mathrm{NaOH}$ was added and the color developed was measured at $420 \mathrm{~nm}$.

\section{Alkaline phosphatase (ALP)}

Serum alkaline phosphatase activity was measured following the method of using disodium phenyl phosphate as substrate. The colour developed was read at $510 \mathrm{~nm}$. Activities are expressed as $\mathrm{KAU} / \mathrm{l}$.

\section{Total bilirubin (TB)}

Serum total bilirubin was estimated following the method of King and Coxon [17]. In brief, $1 \mathrm{ml}$ of serum was mixed with $0.5 \mathrm{ml}$ of diazo reagent, followed by $0.5 \mathrm{ml}$ (NH4)2SO4. The volume was made up to $10 \mathrm{ml}$ with $85 \%$ ethanol. The contents were mixed well and allowed to stand for $30 \mathrm{~min}$ for even distribution of the precipitate. The precipitate was filtered and measured using a colorimeter.

\section{Lipid peroxidation (LPO)}

Heart tissue homogenate was used for the estimation of lipid peroxidation following the method described by [18] in which malondialdehyde (MDA) released was used as the index for lipid peroxidation. In brief, to $0.2 \mathrm{ml}$ of tissue homogenate, $0.2 \mathrm{ml}$ of $8.1 \%$ SDS, $1.5 \mathrm{ml}$ of $20 \%$ acetic acid and $1.5 \mathrm{ml}$ of $0.8 \%$ thiobarbituric acid (TBA) were added. The volume was made up to $4 \mathrm{ml}$ with distilled water and incubated in a water bath at $95.50 \mathrm{C}$ for an hour. The contents were cooled and $1 \mathrm{ml}$ of water and $5 \mathrm{ml}$ of $\mathrm{n}$ butanol/pyridine mixture were added and shaken vigorously. The contents were centrifuged and the organic layer was separated for measurement of absorbance at $532 \mathrm{~nm}$.

\section{Reduced glutathione (GSH)}

GSH was estimated by the method of [5]. Briefly, $0.5 \mathrm{ml}$ of tissue homogenate was precipitated with $2 \mathrm{ml}$ of $5 \%$ TCA. After centrifugation, $1 \mathrm{ml}$ of supernatant was taken and added $0.5 \mathrm{ml}$ of Ellman's reagent (19.8 mg of 5, 5' dithio (bis) nitrobenzoic acid in $100 \mathrm{ml}$ of $1 \%$ sodium citrate) and $3 \mathrm{ml}$ of phosphate buffer. Standards were treated in a similar way and the color developed was read at $412 \mathrm{~nm}$.

\section{Glutathione peroxidase (GPx)}

GPx activity was measured by the method of [27]. To $0.2 \mathrm{ml}$ of buffer, $0.2 \mathrm{ml}$ of EDTA, $0.1 \mathrm{ml}$ of sodium azide and $0.5 \mathrm{ml}$ of tissue homogenate were added. To that mixture, $0.2 \mathrm{ml}$ of glutathione solution and $0.1 \mathrm{ml}$ of hydrogen peroxide were added. The contents were mixed well and incubated at $37{ }^{\circ} \mathrm{C}$ for $10 \mathrm{~min}$ along with the control tubes containing all the reagents but no enzyme. After 10 $\mathrm{min}$, the reaction was arrested by the addition of $0.4 \mathrm{ml}$ of $10 \%$ TCA. $0.2 \mathrm{ml}$ of tissue homogenate was added to the control tubes. The tubes were centrifuged and the supernatant was assayed for glutathione content by adding Ellman's reagent.

\section{Glutathione-S-transferase (GST)}

GST activity was measured by the method of [7]. The reaction mixture containing $1 \mathrm{ml}$ of buffer, $0.1 \mathrm{ml}$ of 1-chloro-2, 4dinitrobenzene (CDNB), $0.1 \mathrm{ml}$ of homogenate and $1.7 \mathrm{ml}$ of distilled water was incubated at $37^{\circ} \mathrm{C}$ for $5 \mathrm{~min}$. The reaction was then started by the addition of $1 \mathrm{ml}$ of glutathione. The increase in absorbance was followed for $3 \mathrm{~min}$ at $340 \mathrm{~nm}$. The reaction mixture without the enzyme was used as a blank.

\section{Catalase (CAT)}

CAT was assayed by the method of [29]. To $1.2 \mathrm{ml}$ of $50 \mathrm{mmol}$ phosphate buffer $\mathrm{pH} 7.0,0.2 \mathrm{ml}$ of the tissue homogenate was added and the reaction was started by the addition of $1.0 \mathrm{ml}$ of $30 \mathrm{mmol} \mathrm{H} 2 \mathrm{O} 2$ solutions. The decrease in absorbance was measured at $240 \mathrm{~nm}$ at $30 \mathrm{~s}$ intervals for $3 \mathrm{~min}$. The enzyme blank was run simultaneously with 1.0 $\mathrm{ml}$ of distilled water instead of hydrogen peroxide. The enzyme activity was expressed as $\mu / \mathrm{mol}$ of $\mathrm{H}_{2} \mathrm{O}_{2}$ decomposed $/ \mathrm{min} / \mathrm{mg}$ protein.

\section{Superoxide dismutase (SOD)}

SOD was assayed by the method of [21]. $0.1 \mathrm{ml}$ of tissue homogenate was added to the tubes containing $0.75 \mathrm{ml}$ ethanol and $0.15 \mathrm{ml}$ chloroform (chilled in ice) and centrifuged. To $0.5 \mathrm{ml}$ of supernatant, added $0.5 \mathrm{ml}$ of $0.6 \mathrm{mmol}$ EDTA solution and $1 \mathrm{ml}$ of $0.1 \mathrm{M}$ carbonate-bicarbonate ( $\mathrm{pH} 10.2)$ buffer. The reaction was initiated by the addition of $0.5 \mathrm{ml}$ of $1.8 \mathrm{mmol}$ epinephrine (freshly prepared) and the increase in absorbance at $480 \mathrm{~nm}$ was measured in a spectrophotometer. One unit of the SOD activity was the amount of protein required to give $50 \%$ inhibition of epinephrine autooxidation.

\section{Statistical analysis}

Statistical analysis of the results was done by one-way analysis of variance (ANOVA) using GraphPad Prism 5 software followed by Dunnet's comparison test for significance. Significance was set at $(\mathrm{p}<0.05)$. Results are presented as mean \pm SE.

\section{RESULTS}

\section{Serum marker enzymes}

Rats administered intraperitoneally with $\mathrm{CCl} 4$ (group II) showed significant elevation $(\mathrm{p}<0.05)$ of marker enzymes ALT, AST, ALP and $\mathrm{LDH}$ in the serum. Total bilirubin content in the serum of CCl4 treated 
groups was also significantly increased when compared to the control group I. However, in groups II and III which received 200 and 400 $\mathrm{mg} / \mathrm{kg}$ body weight of Ecliptaalba respectively, didn't show drastic changes in the marker enzyme levels. The levels of AST, ALT, ALP and
LDH in the serum of Eclipta alba treated groups were well within the range of control group Irats. Similarly, total bilirubin content was also not significantly altered in groups III and IV administered with Eclipta alba when compared to the control group I (table 1).

Table 1: Marker enzyme levels in the serum of different treatment group rats

\begin{tabular}{lllll}
\hline Experimental groups & AST(U/l) & ALT(U/l) & ALP(KAU/l) & LDH(U/l) \\
\hline Group I & $80.48 \pm 0.83$ & $35.55 \pm 0.38$ & $71.23 \pm 0.45$ & $112.52 \pm 0.6$ \\
Group II & $160.5 \pm 3.33^{* *}$ & $86.55 \pm 0.22^{* *}$ & $123.82 \pm 0.36^{* *}$ & $143.01 \pm 1.21^{* *}$ \\
Group III & $85.16 \pm 0.40$ & $38.37 \pm 0.42^{*}$ & $80.92 \pm 0.46^{*}$ & $0.87 \pm 0.18$ \\
Group IV & $85.17 \pm 0.47$ & $37.79 \pm 0.27$ & $77.82 \pm 0.45$ & $112.23 \pm 0.24$ \\
\hline
\end{tabular}

Values are mean $\pm \mathrm{SE}(\mathrm{n}=5)$; Signifigance ${ }^{* *}(\mathrm{p}<0.05) ;{ }^{*}(\mathrm{P}<0.01)$ : Groups II, III, IV

\section{Antioxidant enzymes}

The oxidative stress caused by $\mathrm{CCl} 4$ in the liver was assessed by measuring the levels of lipid peroxidation (LPO) product MDA, reduced glutathione (GSH) and the antioxidant defence enzymes GPx, GST, SOD and CAT. CCl4 administered Group II exhibited significant $(p<0.05)$ elevation of LPO and reduction of GSH in the liver. Similarly, antioxidant enzymes GPx, GST, SOD and CAT were also significantly reduced in liver of rats treated with $\mathrm{CCl} 4$ when compared to the control Group I rats On the other hand, administration of Ecliptaalba (Group III and IV) reduced the severity of $\mathrm{CCl} 4$ toxicity, as evident from the non-significant differences observed in the oxidative stress indicators and antioxidant enzyme levels in these groups. Normal level of LPO, GSH and antioxidant enzymes within the range of control group I signifies the protection offered by Eclipta alba.

Table 2: Marker enzyme levels, lipid peroxidation and glutathione level in the liver of experimental rats

\begin{tabular}{llllll}
\hline Experimental groups & GPX & GST & SOD & CAT & GSH \\
\hline Group I & $110.12 \pm 0.86$ & $15.55 \pm 0.38$ & $13.23 \pm 0.46$ & $112.52 \pm 0.6$ & $5.87 \pm 0.18$ \\
Group II & $85.09 \pm 0.33^{* *}$ & $7.06 \pm 0.22^{* *}$ & $6.7 \pm 0.36^{* *}$ & $82.06 \pm 1.21^{* *}$ & $2.12 \pm 0.14^{* *}$ \\
Group III & $111.23 \pm 0.40$ & $13.37 \pm 0.42^{*}$ & $11.66 \pm 0.35^{*}$ & $102.23 \pm 0.24$ & $4.23 \pm 0.34$ \\
Group IV & $112.45 \pm 0.47$ & $14.79 \pm 0.17$ & $12.82 \pm 0.45$ & $111.13 \pm 0.29$ & $5.22 \pm 0.27$ \\
\hline
\end{tabular}

Values are expressed as GSH (nmole/g tissue), GPX (nmole/min/mg protein), LPO (n mole/mg protein) Values are mean \pm SE $(\mathrm{N}=5$ ), Signifigance ${ }^{* *}(\mathrm{p}<0.05) ;{ }^{*}(\mathrm{P}<0.01)$ : Group I vs Groups II, III, IV

\section{DISCUSSION}

Hepatotoxicity of $\mathrm{CCl} 4$ is because of reductive halogenations catalysed by cytochrome P450 in the liver cell endoplasmic reticulum. This initial reductive halogenations yield $\mathrm{CCl} 3$, with the subsequent rapid formation of a variety of chemically reactive substances. This results in a series of the secondary mechanism responsible for plasma membrane disruption and cell death. Microsomal lipid peroxidation and covalent $\mathrm{CCl} 4$ cleavage products to microsomal and mitochondrial lipids and proteins follow immediately $[9,10]$. These initiate a series of pathological events resulting in cell necrosis [25]. Unsaturated lipids of the endoplasmic reticulum undergo peroxidation with resultant destruction of membrane structure. A chain reaction secondary to formation of free radicals from lipids produces further cellular damage. It is evident that free radical generation and increased lipid peroxidation account for more pathological damages of hepatic cells [18]. In the present study, drastic alterations in the level of serum marker enzymes AST, ALT, ALP and LDH were noted, indicating CCl4 mediated hepatic damages. In addition, bilirubin, an endogenous substance and degradation product of haemoglobin was also found to be significantly elevated in $\mathrm{CCl} 4$ treated rats, which is also a measure of hepatotoxicity) and could be attributed to impaired hepatic clearance due to hepatic parenchymal damage and biliary obstruction. The enzymes ALT and AST are localized in mitochondria and cytosol of hepatic cells, ALP usually found in sinusoidal and bile canaliculi membranes and also in cytosol membranes of golgi apparatuses, endoplasmic reticulum and nucleus. LDH, an intracellular enzyme catalyses the readily reversible reaction involving oxidation of lactate to pyruvate. High concentrations of LDH are found in the liver. Elevation in total serum LDH activity is used as diagnostic indices for organ dysfunction [11]. The grave alterations noted in the present study following CCl4administration are a measure of the extent to which the liver has been damaged. Increased serum concentration of these enzymes indicates that they are leached out of the damaged cells in to the circulation. Since the CCl4 induced hepatotoxicity is due mostly to reactive free radical generation, the antioxidant mediated protective role of Eclipta alba has been assessed. CCl4 treatment significantly elevated the lipid peroxidation as evident from the increased MDA level in the liver tissue. Antioxidant enzymes GPx, GST, SOD and CAT were significantly reduced by $\mathrm{CCl} 4$ intoxication, besides reduction of GSH. GSH is a co-factor for several detoxifying enzymes of oxidative stresses such as glutathione peroxidase and glutathione transferase and scavenges hydroxyl radicals and singlet oxygen species directly and detoxifying hydroperoxides and lipid peroxides [8]. Glutathione, synthesized from the liver is the major source of plasma [12]. It can also regenerate some of the most important antioxidants vitamin $\mathrm{C}$ and $\mathrm{E}$. And hence, it can be assumed that liver damage resulted in a reduction in glutathione level and the antioxidant enzymes. It showed that $\mathrm{CCl} 4$ increased lipid peroxidation and depletion of glutathione. Significant reduction of hepatic glutathione, glutathione peroxidase and glutathione S-transferase in CCl4 administrated rats was reported by [13-15]. Administration of Ecliptaalba extract has exhibited considerable protection against oxidative damage of $\mathrm{CCl} 4$ which is evident from the marker enzymes level and antioxidant enzymes status. The levels of these enzymes were nearer to the control values. Increased glutathione level with a concomitant increase in the antioxidant enzymes and reduced lipid peroxidation product are the indications that Ecliptaalba extract offered significant protection.

The protective effect may be due to rich antioxidant phytochemicals such as phenolics and flavanoes $[19,20]$ reported free radical scavenging activity of Eclipta alba extracts and the presence of antioxidant phytochemicals such as phenolics, flavones and tannins [22-24]. The hepatoprotective action may be attributed to scavenging of free radicals generated by microsomal reduction of $\mathrm{CCl} 4$ and prevention of free radical generation responsible for lipid peroxidation [27, 28,30]. It is clear from the above that Ecliptaalba can be an effective herbal protective agent against a wide variety of liver disorders.

\section{CONCLUSION}

In the present study, it has been observed that Ecliptaalba herbal extract offered significant protection against the hepatotoxicant 
CCl4. The marker enzyme levels and the important antioxidant enzymes activity were greatly protected, besides reducing lipid peroxidation by the herbal extract, showing that this plant is a better remedy for any diseases of the liver. The study also shows that plant extract has considerable antioxidant property.

\section{ACKNOWLEDGEMENT}

The author are grateful to express her sincere thanks to the chairman, Directors, Principal and the Head of the Department Mohamed Sathak College of arts and science for the encouragement and facilities provided to carry out this research work.

\section{AUTHOR CONTRIBUTION}

All the work have been carried out by me.

\section{CONFLICT OF INTERESTS}

Declared none

\section{REFERENCES}

1. Beddowes, Faux. Chloroform, carbon tetrachloride and glutathione depletion induce secondary genotoxicity inliver cell via oxidative stress. Toxicology 2003;187:101-15.

2. Priya G, Chellaram C. In vivo hepatoprotective effect of Trianthemadecandra extracts on carbon tetrachloride induced Rats. J Chem Pharm Res 2011;3:154-8.

3. Bhargava, Seshadri TR. Chemistry of medicinalplants: Eclipta alba and Wedeliacalendulacea. J Res Indian Med 1974;9:9-15.

4. Cabre, Camps. Time courseof changes in lipid peroxidation and glutathione metabolism in rats withcarbon tetrachlorideinduced cirrhosis. Clin Exp Pharmacol Physiol 2000;27:694-9.

5. Cassidy WM, Reynolds TB. Serum lactic dehydrogenase in the differential diagnosis of acute hepatocellular injury. J Clin Gasteroenterol 1994;19:118-21.

6. Ellman GL. Tissue sulfhydryl groups. Arch Biochem Biophys 1959;82:70-7.

7. Ferenci P, Dragosics B. Randomized controlled trial of silymarin treatment in patients with cirrhosis of the liver. J Hepatol 1989;9:105-13.

8. Habig WH, Pabst MJ, Jakoby WB. Glutathione-stransferases: the first enzymatic step in mercapturic acid formation. J Biol Chem 1974;249:7130-9.

9. Hagerstrand I. Distribution of alkaline phosphatase activity inhealthy and diseased human liver tissue. Acta Path Microbiol Scand A 1975;83:519-26.

10. Handa SS, Sharma A, Chakravarti KK. Natural products and plants as liver protective drugs. Fitotherapia 1986;57:307-12.

11. Hensley K, Robinson K, Gabbita SP, Salsman S, Floyd RA. Reactive oxygen species, cell signalling, and cell injury. Free Radical Biol Med 2000;28:1456-62.
12. Higuchi $\mathrm{H}$, Gores GJ. Mechanisms of liver injury: an overview. Curr Mol Med 2003;3:483-90.

13. Kaplowitz N. Biochemical and cellular mechanisms of toxic liver injury. Semin Liver Dis 2002;22:137-44.

14. Kaplowitz, Ookhtens M. The regulation of hepatic glutathione. Annu Rev Pharmacol Pharmacol Toxicol 1985;25:715-44.

15. Kataki MS, Ahmad AZ, Avasthi D, Tomar B, Mehra P, Yadav RS, et al. In vitro antioxidant profile of Wedeliacalendulacea leaves. Pharmacologia 2012;3:75-83.

16. King EJ, Coxon RV. Determination of bilirubin with precipitation of the plasma proteins. J Clin Path 1950;3:248-59.

17. King PD, Perry MC. Hepatotoxicity of chemotherapy. The Oncologist 2001;6:162-76.

18. Loguercio C, Federico A. Oxidative stress in viral and alcoholic hepatitis. Free Radical Biol Med 2003;34:1-10.

19. McClements J, Decker EA. Lipid oxidation in oil-water emulsions: impact of molecular environment on chemical reactions in the heterogeneous food system. J Food Sci 2000;65:1270-82.

20. Meena AK, Rao MM, Meena RP, Panda P, Renu. Pharmacological and phytochemical evidence for the plants Wedeliagenus-a review. Asian J Pharm Res 2011;1:7-12.

21. Mehendale HM. Role of hepatocellular regeneration and hepatocellular healing in the final outcome of liver injury: a two stage model of toxicity. Biochem Pharmacol 1991;42:1115-62.

22. Misra H, Fridovich I. The role of superoxide anion in the autooxidation of epinephrine and a simple assay for superoxide dismutase. J Biol Chem 1972;247:3170-5.

23. Ohkawa H, Ohishi N, Yagi K. Assay for lipid peroxidation in animal tissue by the thiobarbituric acid reaction. Anal Biochem 1979;95:351-8

24. Rao KS, Recknagel RO. Early onset of lipoperoxidation inrat liver after carbon tetrachloride administration. Exp Mol Pathol 1968;9:271-8.

25. Recknagel RO, Glende EA Jr. Carbon tetrachloride hepatotoxicity: an example of lethal cleavage. CRC Crit Rev Toxic 1973:2:263-97.

26. Reitman S, Frankel S. A colourimetric method for the determination of serum glutamic oxaloacetic and glutamic pyruvic transaminases. Am J Clin Pathol 1957;28:56-63.

27. Rotruck JT, Pope AL, Gauther HE, Swanson AB, Hafeman DG, Hoekstna WG. Selenium: biochemical roles as a component of glutathione peroxidase. Science 1973;179:588-90.

28. Subrata De, Ravishankar B, Bhavsar GC. Plants with the hepatoprotective activity-a review. Indian Drugs 1994;30:355-63.

29. Takahara S, Hamilton BH, Nell JV, Ogubra TY, Nishimura ET Hypocatalasemia: a new genetic carrier state. J Clin Invest 1960; 39:610-9.

30. Wagner H, Geyer B, Kiso Y, Hikino H, Rao GS. Coumestans as the main active principles of the liver drugs Eclipta alba and Wedelia calendulacea. Planta Med 1986;5:370-4. 